\title{
Post-Socialist Aspirations in a Neo-Danwei
}

\author{
Tom Cliff*
}

\begin{abstract}
A B S T R AC T
The socialist-era danwei lives on in contemporary, ever-reforming China. Ironically, the processes of reform helped to enable the perpetuation of the traditional danwei's paternalistic practices by concentrating monopoly power in selected, partially market-listed, centrally owned enterprise groups. The Tarim Oilfield Company is an outstanding example of this balancing act between socialist and market structures-a neo-danwei. This article maps these structures using detailed ethnographic data gathered over two years working in the company. Multiple subjective viewpoints show that distinctions between different categories of employee are crucial to maintaining the danwei in the midst of marketization. Like the socialist-era danwei, the oil company produces dependency and constrains social mobility. Yet, amidst glorification of open competition and individual achievement, the desire to enter a danwei is as strong as ever. The certainty of danwei life is highly valued; stability becomes a status symbol.
\end{abstract}

$\mathrm{M}$ ary desired and resented status. We sat in an expensive coffee shop with a Western menu and spoke, in English, about the structures of life in the Tarim Oilfield Company, where she worked. The company is a Central StateOwned Enterprise (Central SOE, yangqi 央企), located in the city of Korla, South Xinjiang. It is exclusive, accepting only a few top graduates each year as permanent employees, and is widely recognized as "the best work unit in Korla" (Ku'erle zui hao de danwei 库尔勒最好的单位). ${ }^{1}$

To people outside the oil company, Mary's institutional identity marked her out unequivocally as one of the élite, but Mary saw her position as a temporary

\footnotetext{
* I would like to thank Andrew Kipnis, Luigi Tomba and two anonymous reviewers for their valuable comments on reshaping this paper.

1. This article is based on over two years of ethnographic research in Korla and surrounds, while I lived in the Tarim Oilfield Company compound and worked as an English teacher at the oil company school. This was an invaluable public identity, although I made no secret of the fact that I was also a scholar researching "Han Lives in Xinjiang". While I did not personally know everybody who lived in the compound (population approximately 10,000), most people with school-age children knew of me. Almost all of the formal interviews were conducted in the last eight months of my fieldwork, after I had built up trust with key people; from these key people, I "snowball sampled", and then cross-checked the interviewees' responses during informal conversations. The interviews themselves took the form of life-histories, to engage the interviewee and allow facts and stories to emerge spontaneously as well as to give a sense of how different cohorts were affected by changing state policies.
}

The China Journal, no. 73. 1324-9347/2015/7301-0006. Copyright 2015 by The Australian National University. All rights reserved. 
employee as liminal and unsatisfactory. Other women in similar positions were working as waitresses before they "married in" to the oil company, but she was educated at a good university and held a professional job before coming to Korla with her PhD-holding husband. He was sent to get some practical experience in Xinjiang, before returning to the headquarters of China National Petroleum Corporation (CNPC) in Beijing to continue a career in research management. Mary told me that they had decided not to take up an offer that her husband had received from a foreign oil company, because the behavior of expats in Beijing had convinced her that foreigners were not really as "civilized" as her teachers at school and university had led her to believe. Moreover, the competing offer from CNPC promised him rapid promotion and offered them both a lifetime of high status.

Mary explained that, in the Tarim Oilfield Company, "your [employment] status decides everything". She noted the "really quite different" way in which temporary employees are treated, compared to permanent employees:

For example, a few days ago the secretary of my office told me to pick up a box of mooncakes before I went home for the mid-Autumn Festival. That day, I finished my work early, picked up a box of mooncakes and went to my car. Just then, my telephone rang. It was my leader. He said "You are not a [permanent] worker-you must return the mooncakes". You know, now I am nearly 30 years old-I've never had that kind of feeling. I got tears in my eyes; my self-respect fell ... I was hurt deeply. I was really, really angry ... when I went back and met my leader, I shouted: "I don't care about a box of mooncakes, but you need to be clear".

Mary noted that similar conflicts often broke out around her, and placed the blame on "the system of the company". The following day, the secretary of Mary's unit called her to announce that all temporary workers would also be allocated mooncakes, as a direct result of her "making a fuss".

In this case, "the system" created a problem of social stability to which managers clearly felt compelled to respond: disgruntled temporary workers have the potential to affect the permanent workers to whom many of them are married. Maintaining social stability is a primary requirement of any leader in China, and mooncakes are not expensive, so the response from the leaders seems explicable, ${ }^{3}$

2. The phrase comes from a report by the Social Development Research Group at Tsinghua University; see "New Thinking on Stability Maintenance: Long-Term Social Stability Via Institutionalized Expression of Interests" (13 May 2010), originally published in Chinese in Nanfang zhoumo (Southern Weekend) on 14 April 2010 (English translation formerly available at http://chinaelectionsblog.net/?p=5220, accessed 16 May 2011), which suggests that "making a fuss" has become one of the negotiating tools for people and groups denied legitimate institutionalized expression of interests.

3. The institutional requirement to maintain social stability has always been particularly emphasized in ethnically complex Xinjiang, and this has been further accentuated as a result of increasingly frequent and 
but why the distinction in the first place? If such low-level conflicts are not uncommon, why are materially insignificant entitlements such as mooncakes so bitterly disputed? ${ }^{4}$ On the other hand, the angry words "I don't care ... but you need to be clear" imply an acceptance (albeit, perhaps, a grudging one) of differential treatment, as long as the entitlements and opportunities associated with different statuses are clearly defined and consistently applied. Mary's reaction to the misinformation, and then about-face, regarding the entitlement to mooncakes suggests that expectations play a large part in attitudes to entitlements at the danwei. The expectations that employees have of the system, and whether or not these expectations are met, directly affect social stability within the work unit. Of particular relevance here are employee expectations of treatment according to status and opportunities to change this status through social mobility, and how these expectations interact with institutionalized constraints on such opportunities.

Yanjie Bian's 2002 survey article, "Chinese Social Stratification and Social Mobility", asserts that "post-1978 market reforms and the rise of labor markets [have made] social mobility a living experience for almost everyone". ${ }^{5}$ However, as Mary noted in her conversation with me, even in this relatively high-status work unit, many ordinary employees do not seem to aspire to "move up the ladder" and, moreover, discourage such aspirations in other employees:

When I first came and used to recite English material, many people around me were surprised. [They asked]: "Why do you study? Your salary is not related to your labor." If I work hard, at the end of the month I will get 2500 yuan salary. If I sleep in the office, I can still get 2500 yuan salary. This is because [the Tarim Oilfield Company] is a [state-owned enterprise].

The distinctions between permanent and temporary employees, and an apathetic "danwei mentality" among certain groups of employees, suggest that elements of the low-social-mobility "status hierarchy" 6 of the Mao era persist in the Tarim Oilfield Company. Yet Mary's husband has already been rapidly promoted and is apparently being groomed for an even higher position in the Beijing head office. The two members of this family live in two different socioeconomic worlds, a

often fatal inter-ethnic violence since the Ürümqi riots in July 2009, see Thomas Cliff, "The Partnership of Stability in Xinjiang: State-Society Interactions Following the July 2009 Unrest”, The China Journal, No. 68 (July 2012), pp. 79-105.

4. Mooncakes are materially insignificant entitlements, because nobody in the Tarim Oilfield Company is short of food or money, most people would be thoroughly sick of mooncakes by the end of the mid-autumn festival period, and these mooncakes would be all but valueless to pass on as a gift (they would be instantly recognizable as the ones given out by the work unit, implying that the giver holds the receiver in low esteem).

5. Yanjie Bian, "Chinese Social Stratification and Social Mobility", Annual Review of Sociology, Vol. 28 (2002), p. 104.

6. Yanjie Bian, "Chinese Social Stratification and Social Mobility", p. 104. 
situation that raises questions touching on some of the key categories of analysis in previous studies of social mobility in post-reform China. Who has access to inter-firm mobility or career mobility within the firm? What is the effect of gender on social mobility? How are transitions from "outside the system" (tizhi wai 体制外) to “inside the system” (tizhi nei 体制内) achieved or obstructed? Structurally, these anecdotes raise the question of what other socioeconomic worlds exist within the Tarim Oilfield Company. To what extent are vestiges of the socialist-era danwei still present? How have they been modified or replaced? To what effect? In answering these questions, I will also outline the possibilities for inter-generational mobility, since this is a key concern of oil company employees, and is closely associated with both expectation and danwei form.

My approach to these questions is to treat structure and agency as two parts of a continuing process, and thus as equally important-although not necessarily equally influential on outcomes at any given point in time. Throughout this article, I explore the formal and informal rules and structures of the Tarim Oilfield Company, paying close attention to individual reactions to them. I find that both the social mobility of employees and their expectations more broadly are influenced strongly by both formal and informal systems which classify them into status groups with certain entitlements and opportunities. At the same time, and as seen in the above examples, employee expectations and actions change their environment.

\section{THE DANWEI AT THE CENTER OF THE CITY}

The common statement that the Tarim Oilfield Company is "Korla's best work unit" signals that many people in Korla think primarily in terms of "workplace identification", rather than "the occupation of wage work", when assessing attained status. ${ }^{7}$ Faced with limited prospects for social advancement (or even material security), many young local women of marriageable age act this out in their preferred choice of partner. As a teacher in the oil company school, I was asked on a number of occasions to act as a matchmaker for local women who wanted to marry an oil company employee: "he can be divorced, that's okay, and he doesn't have to be good-looking, he just has to be kind-or even reasonably kind-and not too old". At the opposite end of the educational-status spectrum, some of China's top-scoring students in oil exploration engineering, geology and other relevant fields compete for acceptance into CNPC-one of the most economically powerful (and, at the time of this research, politically influential) SOE groups in China. New recruits, predominantly male, strut proudly around the oil company compound, knowing full well that they have laid the groundwork for

\footnotetext{
7. Yanjie Bian, "Chinese Social Stratification and Social Mobility", p. 105. See also Nan Lin and Yanjie Bian, "Getting Ahead in Urban China”, American Journal of Sociology, Vol. 97, No. 3 (1991), pp. 657-88.
} 
their future economic security and privilege. A job in, or marriage into, the Tarim Oilfield Company is seen as an "iron rice bowl", and more: the many expensive retail stores and entertainment venues in Korla owe their existence to the high consumption capacity of oil company employees.

The oil company danwei is at the center of the city of Korla, both figuratively and physically. It has both administrative and spatial dimensions-a fact reflected in its everyday designation, Tazhi (塔指), which means Tarim Headquarters. ${ }^{8}$ The oil company compound dominates the landscape over the river from the old city center and, since it was formally established in 1989, the company's social, political and economic influence has reshaped Korla. Korla is arguably now Xinjiang's "second city" with regard to its political and economic profile, and it is by far the most modern and economically powerful county-level city in South Xinjiang. Notably, it was consumption by the highly paid oil company employees, rather than oil and gas production per se, that drove the city economy to these heights. Taxes levied on oil and gas production went primarily to the central government, at least until the new resources tax law came into operation in July $2010 .{ }^{9}$ Such vertical links continue to be of primary importance to the Tarim Oilfield Company: in the national bureaucratic ranking system, it is just one step below the province or ministry level, and one step above the county-level rank of Korla City itself. This means that the oil company is not directly subject to the authority of the local government within whose administrative region it operates and is physically located. A number of people told me: "Tazhi, that piece of land, does not belong to Bazhou [Prefecture] or to Korla; it belongs to the nation [the political center]". ${ }^{10}$ Although certain plans and proposals must pass city government approval, the oil company's bureaucratic status and economic clout mean that it is in effect independent of local government. One thing which this partial auton-

8. "Tazhi” is an abbreviation of Talimu youtian gongsi zhihuibu (Tarim Oilfield Company Headquarters), and may be used to refer to the company or to the compound which it occupies. Thus, a person could say "I work for Tazhi", or they could say "I am going to Tazhi". The vernacular use of "Tazhi" almost always implies something of both of these meanings, for example, the sentence "Tazhi is hard to get into".

9. "China Overhauls Natural Resource Tax: The Pockets of Local Governments Are Bound to Swell Quickly Due to the Natural Resource Tax Overhaul", Caixin (21 June 2010), available at http://english.caixin .cn/2010-05-21/100146123.html (18 November 2011). A city government official told me that 50 per cent of the Korla City government's taxation base in 2009 derived from the tertiary sector (retail, real estate and services), with only 50 per cent due to the primary and secondary sectors (agriculture, resource extraction and manufacturing) combined.

10. The Tarim Oilfield Company is directly administered (zhixia) by the Xinjiang oil management bureau, which is in turn overseen by a ministerial-level unit in Beijing. The city government is only the third player in the political government of Korla. The city government's bureaucratic status is only county level (theoretically on par with the rest of the counties in that prefecture), compared to the prefectural-level statuses of the Production and Construction Corps (bingtuan) and oil companies. Despite this, the city government takes decisions about nearly everything in Korla City area which does not directly affect either the bingtuan Second Agricultural Division, the Tarim Oilfield Company or the military (which also holds prefectural-level rank). The latter three centrally administered institutions make the decisions about matters on their own turf, and negotiate with the city on areas of common interest. 
omy means in practice is that the oil company performs a range of administrative and service functions which are officially the concern of government proper.

Tazhi is the youngest (most recently established) of all CNPC's regional oil companies. The difficulty-due to both shifting-sands desert conditions above ground and complex geology below-of extracting oil from the Tarim Basin meant that exploration teams in the 1950s, 1960s and 1970s all failed to locate and tap a viable source. The discovery and exploitation of the Tarim Number One well in 1986 is a point of great pride for the pioneers of that day, who are the oldest of the oil company permanent employees. Their success was made possible by imported technology (including desert-going Mercedes-Benz trucks) that only became available after the start of China's reform and opening up. The desert's unforgiving physical conditions thus played a key role in determining the historical moment of institutional emergence.

The Tarim Oilfield Company's institutional structure was, in turn, influenced by the timing of its establishment. The reform era transformed China's alreadycompromised and internally contradictory social contract; among other things, reducing the workforce became both permissible and desirable. ${ }^{11}$ The Tarim Oilfield Company accounts for only 12,000 of China's approximately 1 million permanent oil company employees, while older oilfields like Karamay (established in North Xinjiang in 1954) and Daqing (established in Heilongjiang in 1960) have over 100,000 permanent employees. ${ }^{12}$ Tazhi did not need to lay off staff to produce this relatively lean condition-building from a base of fewer than 400 employees, managers had only to limit the number of permanent employees taken on each year. As I shall show, Tazhi is an artefact of the transition from danwei-type employment conditions to a reform-era type of social contract. By this, I mean that partial transition is embodied in the formal structure of the company, as well as in the informal structures of expectation and practice (the "moral economy") ${ }^{13}$ that the company and its employees create in their interac-

\footnotetext{
11. Wenfang Tang and William L. Parish, Chinese Urban Life Under Reform: The Changing Social Contract (Cambridge: Cambridge University Press, 2000), pp. 3ff.

12. The China National Petroleum Corporation (hereafter CNPC) employed over 1.5 million people at the time of its listing on the stock exchange in 2000. Even after recurrent layoffs through the early 2000s, over 1 million people were employed in extracting petroleum and natural gas in China by the end of 2008 . See Ministry of Labor (ed.), Zhongguo laodong tongji nianjian (China Labor Statistical Yearbook) (hereafter ZGLDTJNJ) (Beijing: China Statistical Press, 2009), section 3-1. In 2014, CNPC had about 540,000 permanent employees, see Renmin ribao (People’s Daily, hereafter RMRB), "Zhong shiyou Daqing youtian shu qian zhigong kangyi gaige zinü bao fenpei” (1000 Daqing Oilfield Employees Oppose the Reform of Children's Guaranteed Job Assignments) (30 April 2014), available at http://politics.people.com.cn/n/2014/0430/c1001 -24959922.html, accessed 2 June 2014. The total number of people employed by the Tarim company, including contractor employees, is close to 30,000. Only 4,000 of the Tarim Oilfield Company's 12,000 permanent employees are working directly under the auspices of the Tarim headquarters; 2,000 are attached to the petrochemical facility (Tashihua) and 6,000 to a small and old oil field in southwest Xinjiang.

13. For the original articulation of this concept, see E. P. Thompson, "The Moral Economy of the English Crowd in the Eighteenth Century", Past \& Present, No. 50 (1971), pp. 76-136.
} 
tion. The formal institutional structure is known as "the Tarim model" (Talimu moshi 塔里木模式).

The "Tarim model" is lauded as "completely new" and a "successful practice" on the official website of the Tarim Oilfield Company's parent, CNPC. ${ }^{14}$ The latter claim is fairly well-founded, in economic and technical terms. ${ }^{15}$ Claims of structural novelty in employer-employee relationships, however, require a more complex assessment. A primary aim of this article is to outline how the Tarim Oilfield Company is similar to and where it differs from the socialist-era work unit, and how these similarities and differences in structure affect the formal social contract for different types of employees.

\section{NEO-DANWEI}

Tazhi resembles a traditional work unit-a danwei. In the socialist era, a danwei "provided all essential services [including housing, food ration, education, et cetera], produced economic and political dependency", and was the primary way for employees to interact with the state. ${ }^{16}$ In Tazhi, these "essential services" have been updated to the modern era and adjusted to an élite level commensurate with the company's strategic and monopoly status. Along with the company's administrative headquarters and office blocks, the Tarim compound contains a hospital with the best equipment in town, a school, a cinema, a cultural center with free or heavily subsidized activities, an expensive sporting complex and swimming pool, and even a city-district-level police station. Human and capital resources are concentrated in Tazhi. Although Tazhi is not an official level of government,

14. CNPC, Talimu moshi-xie zai Talimu shiyou huizhan 20 zhou nian zhi ji (The Tarim Model-Inscribed on the $20^{\text {th }}$ Anniversary of the Tarim Petroleum Exploration Campaign) (8 April 2009), available at http://news .cnpc.com.cn/system/2009/04/08/001232150.shtml, accessed 18 May 2012.

15. The deep and difficult-to-drill angled wells that are the norm in the Tarim basin apparently cost 1.4 times as much as a standard straight well, but their yield is 3.5 times as much. See CNPC, Talimu moshi. Using official statistics of yearly crude oil and natural gas outputs and the labor force of the oil and gas extraction industry for China as a whole, along with Tarim-specific statistics reported by Reuters, I calculate that Tazhi produced about 7.4 per cent of China's oil equivalent in 2010, with only about 1.2 per cent of the permanent workforce. See ZGLDTJNJ, section 3-1; Reuters, "PetroChina to Raise Output in Tarim Oilfield 50 pct by 2015", Thomson Reuters (17 May 2011), available at http://af.reuters.com/article/energyOilNews /idAFL4E7GH03320110517, accessed 10 May 2012; National Bureau of Statistics (ed.), Zhongguo nengyuan tongji nianjian (China Energy Statistical Yearbook) (hereafter ZGNYTJNJ) (Beijing: China Statistical Publishing House, 2010), sections 3-4, 3-9; China Data Online, Natural Crude Oil Production and Output, 2012, China Yearly Industrial Database, available at http://chinadataonline.org.rp.nla.gov.au/member/hyn /hyntshowpd.asp?hy=07\&code=00413, accessed 21 May 2012; China Data Online, Natural Gas Production and Output, 2012, China Yearly Industrial Database, available at http://chinadataonline.org.rp.nla.gov.au/member /hyn/hyntshowpd.asp?hy=07\&code=00420, accessed 21 May 2012.

16. Luigi Tomba, "Making Neighbourhoods: The Government of Social Change in China's Cities", China Perspectives, Vol. 4 (2008), p. 51; Andrew G. Walder, Communist Neo-Traditionalism: Work and Authority in Chinese Industry (Berkeley: University Of California Press, 1986). 
it is seen as governmental and performs many governmental roles. Offices within the Tarim compound provide services such as security, fire protection, hygiene, central heating, education, family planning and household registration. It is theoretically possible for an entire family to go about a normal life without ever leaving the Tarim compound.

The oil company does not undertake the paternalistic and all-encompassing role of the socialist-era work unit for all employees and their families. Rather, it classifies employees into three basic types-permanent, contractor and temporar $y^{17}$ - to which varying degrees of entitlement are granted. Permanent employees, the true élite of Tazhi, are the only ones to get the full benefit of the services; contractor and temporary workers are not considered full members of the "danwei family". Both permanent and temporary Tazhi employees have a direct employment relationship with one of the sub-companies of the Tarim Oilfield Company. However, temporary employees are not eligible for promotion, and their insurance benefits are limited to the health, unemployment and retirement benefits dictated by national-level regulations for all SOEs. At best, these insurance benefits come out at about one-third of the value of the benefits received by permanent employees of the Tarim company. The contractor workforce is employed by one of the many state- and privately owned companies that tender to provide specific services to Tazhi; these are known as "contractor service companies" ( yifang fuwu danwei 乙方服务单位; hereafter, contractors). ${ }^{18}$ They must depend on their own, external, work unit for salary and benefits. Neither contractors nor temporary workers have the right to buy a (companysubsidized) apartment in the Tarim compound. This classification system is called “three modes of employment" (san zhong yonggong 三种用工). Naturally, a hierarchy also exists among the permanent employees of the Tarim Oilfield Company. Although technical skills, level of education, length of service and area of operations are also important factors in determining remuneration, bureaucratic rank is the pre-eminent marker of social distinction here.

The classificatory categories outlined above are not a new phenomenon in China. Forms of outsourcing were the rule, rather than the exception in certain large industries in Republican-era China; and SOEs used temporary workers even at the height of the socialist era. ${ }^{19}$ Contractors are now once again a

17. The CNPC website uses the following terms: permanent (guding); contractor (jiepin); temporary (linshi) - a " 3 -in-1" employment system (san wei yi ti yonggong zhidu). See CNPC, Talimu moshi. In the parlance of the Tarim Oilfield Company, permanent employees are also referred to as "contracted" employees (hetonggong). In practice, contract renewal for permanent employees is assumed; none of my interlocutors could think of an example to the contrary. My use of the term "contractor employee" as the English translation of jiepin denotes that they are employees of contractors.

18. The Tarim company is the Party A (jiafang) to the contractor's Party B (yifang).

19. Andrew G. Walder, Communist Neo-Traditionalism, pp. 30, 48-56. 
common phenomenon in workplaces across the country. ${ }^{20}$ There are specific and identifiable precedents for many of the component parts of the neo-danwei, but there are no examples in the literature of them all existing simultaneously within the one institution. The term "neo-danwei" implies a resilience of traditional socialist forms of enterprise organization and its social structures, adapted to the new economic conditions.

\section{THE TARIM MODEL}

The core of the Tarim model is an operating principle known as "two new and two high" (liang xin liang gao 两新两高). The two “high" aspects are high standards (gao shuiping 高水平) and high returns (gao xiaoyi 高效益), while the two “new" aspects are new technology ( $x$ in jishu 新技术) and new company structure ( xin tizhi 新体制). A senior oil company manager, Department Director Xie, explained to me that the term "high standards" means setting a high standard for employment of permanent personnel, ${ }^{21}$ and requiring of them that they finish the job to a high standard. "High returns" means a high return on investment. New technology means mechanization and computerization, with one of the main aims being to reduce the workforce: "In the past we would have about 30 people in the control room, but now we only need two. This technology ... means that we can cut off lots of employees." As he said this, he made a slow chopping action with his right hand, as if shearing meat off a doner kebab.

The "new company structure" of the Tarim Oilfield Company is unique among the CNPC regional oil companies, and refers specifically to the practice of subcontracting tasks as diverse as exploration, high school teaching and entertainment to "contractor service companies". The primary reason for such a structure is to decrease the number of permanent employees maintained by the Tarim company, and thus reduce the amount paid out on retirement and non-salary benefits. "To maintain our current level of production, we employ $[12,000]$ people, but if we used the old company structure, we would have to employ 100,000 people", Director Xie told me. Tazhi outsources on a far greater scale than any other regional oil company in China. Contractor employees account for 60 per cent of the workforce, and 75 per cent of the "Party B" contractors are not directly subordinate to the Tarim Oilfield Company. While it is not uncommon for

20. Anita Chan and Jonathan Unger, "A Chinese State Enterprise Under the Reforms: What Model of Capitalism?”, The China Journal, No. 62 (July 2009), p. 4.

21. Since the early 1990s, new permanent personnel have been sourced exclusively from among college graduates. Today, Tazhi takes only the cream of these graduates. The company smugly points out that they have gone from a situation where they "request people" (qing ren) to one where they "choose people" (xuan ren). See CNPC, Talimu moshi. 
permanent and temporary employees to work side-by-side in the same small team or work unit, the teams of contractor employees tend to work quite separately.

The scope of Tazhi's outsourcing is also unmatched, and contractor employees' socioeconomic status varies greatly, depending upon the type of services provided to Tazhi by the company that employs them (as well as their occupational position and their employment relationship with the contractor). Among the élite and the most highly skilled of the contractors to Tazhi are teams belonging to other regional oil companies-the teams set up companies within the Tarim compound and compete for tenders put out by the Tarim Oilfield Company. These teams are found in greatest concentrations at the "front line" - that is, the desert, where they work on exploration, drilling, production and "oilfield construction". There are over 170 teams from other regional oil companies working for the Tarim Oilfield Company, and they make up the bulk of the contractors. ${ }^{22}$ These contractors employ both permanent and temporary employees, whose employment relationship is not with Tazhi but ultimately with one or another of the "parent" regional oil companies. The permanent employees of these contractors are well paid by their own parent company-as long as they keep winning contracts from Tazhi-but they are eligible for only some of the benefits of the Tarim compound. Despite the fact that some of these contractor employees have been living in Korla and servicing Tazhi since its inception 20 years ago, they do not fall under the paternal umbrella of the Tarim Oilfield Company. The profits of these exploration contractors eventually flow back to the parent regional oil company. In other words, much of this outsourcing happens between regional oilfield companies within CNPC. This system is made possible by the fact that, while there is much exploration and exploitation still to be done in the Tarim Basin, the output of many oilfields in other parts of China has plateaued or is declining. Consequently, many of the other regional oil companies retain excess employees, even in skilled occupations like exploration.

Many contractor employees, however, are in far less lucrative lines of business. Although these employees may enjoy slightly inflated wages compared to somebody doing a similar job for other local companies, many have no job security and receive little more than their wage in compensation. Employees of the contractors providing hospitality and entertainment services at the "front line", for example, may be migrants from elsewhere in China, or may be locals, and tend to be young and ethnically Han. Still other parts of the Tazhi workforce, broadly classified (by the oil company) as "contractors" ( yifang 乙方), do enjoy a degree of job security, but did not choose to come to Korla. Like the exploration

22. CNPC, Talimu moshi. 
contractors, they were sent there by their company or institution; the company is usually linked in some way to the oil industry. For example, Jianghan (江汉) oil field in Hubei (run by SinoPec [Zhongguo shihua 中国石化]) has an arrangement with the Tarim oil field to supply high school teachers to the oilfield school. Teachers of all ages from Jianghan generally come on three-year rotations. They receive very little extra salary, and if they refuse to come they lose their job back at the Jianghan oilfield school. For young teachers with saleable skills, quitting and returning east remains an option-especially for unmarried young women, or those who are recently married and want to have children. For older teachers who are close to retirement, however, quitting would mean a loss of their coveted permanent status at Jianghan, along with their retirement pension and other benefits. These latter have no choice but to stick out the three years in exile.

The newly arrived high school teachers are broken in by sending them to pick cotton for between one and two weeks. For the physically weak among them, this experience borders on the traumatic. They return with welts on their arms, allergic reactions to the chemicals sprayed on the cotton, sunstroke, sore legs and backs, and darkened skin. The cotton-picking excursion is framed by the oil company as character-building-teaching the soft eastern urbanites how to put up with hardship. However, it is more often received, firstly, as a demonstration of the oil company's ability to exercise arbitrary authority over the lives of these conscript-teachers and, secondly, as a crystal-clear statement of their "place" at or near the bottom of Tazhi's internal hierarchy.

The Jianghan teachers are housed in basic hotel-style accommodation, alongside other seconded personnel (from petroleum research institutes and universities elsewhere in China, for example) and unmarried graduate employees (who spend most of their time at the "front line"). The building is not set up to be homely; it is simply a place to sleep between work shifts. All the people who live there are expected, first and foremost, to labor productively, and the rooms are equipped accordingly. A double room simply means two single beds. Very few rooms have attached toilet and bath facilities, and none of the rooms are set up for cooking. They are expected to eat at the nearby canteen. By doing so, they save on food preparation time (leaving more time for work) and reduce the living space needed per individual. The combined effect of long work hours and the lack of a place to feel at home is that, during these secondments, workers have very little opportunity to build up their social networks in Tazhi or in Korla. The lack of cooking facilities is one of the most disturbing aspects of life in Tazhi for most of the female conscript-teachers. For them, cooking and eating familiar food is a central part of feeling at home, and they became very excited when my Canadian colleague and next-door neighbor invited them to use her kitchen. An entire troupe of them came over and cooked up a great variety of "comfort food" dishes. My colleague said that she had never seen them so happy. This deprivation of private socializing space is, at a very personal and gendered level, part of 
what it means to be a resident without full citizenship rights in the Tarim Oilfield Company. ${ }^{23}$

The seconded employees, the teachers from Jianghan being the largest group, are not "of the Tarim company"; they are simply being supplied (as if, or even as, a commodity) to the Tarim company in a business deal with another company. Although they have some attachment to this latter company, and may even be permanent employees entitled to full benefits, these rights do not apply to their relationship with the Tarim Oilfield Company. Tazhi has no paternal responsibility towards these contractor employees and, since they are seen as replaceable, they are treated as expendable.

\section{SELECTIVE PATERNALISM: DISTINCTIONS, DEPENDENCY AND DISCONTENT}

Tazhi's paternalism covers a range of benefits and services for permanent employees that surpasses what SOEs are officially allowed to provide. The popularly understood justification for this is the company's location on the frontier, where certain services and opportunities are scarce or unavailable. In other words, the yardstick by which an acceptable standard of living is judged is that of Beijing, not Korla. Aside from the cash salary, the benefits granted to permanent employees include an in-house pension scheme, supporting K-12 educational facilities and offering reserved university positions for their children, providing jobs for their spouses and, since 2008, making jobs available to graduated children through an "internal entrance examination". Note the strong focus on family members' social mobility. These arrangements could be characterized as a form of occupational welfare, and they clearly produce dependency on at least two scales-first, of the family on the work unit and, second, of the family members on the permanent employee.

\section{Salary and bonus}

The salary package that the Tarim Oilfield Company provides to its permanent employees demonstrates the all-encompassing paternalistic socioeconomic role that the company plays in their lives. Various sorts of bonus form the major part of an oil worker's cash income. The largest of these is the twice-yearly "productivity bonus" (xiaoyi gongzi 效益工资), which can amount to 60,000 yuan yearly

23. The school's headmaster, also from Jianghan, is barely more privileged than his charges (the head tends to be a man, as he is responsible for keeping the other Jianghan teachers in line). When I was there in 200710 , he lived with his wife and his high-school-aged daughter in the same style and size of apartment that we foreign teachers occupied: $65 \mathrm{~m}^{2}$, with a bedroom, a living room and a study, all small. The headmaster tends to stay for at least three years (one rotation), and may well be asked to stay for longer. 
for an unranked permanent employee. A low-level cadre may get 90,000 yuan, and the bonus increases considerably with rank. In comparison, even the official average salary in Korla only reaches 28,000 yuan per year. ${ }^{24}$

A veteran Tazhi employee explained that salary is paid according to bureaucratic rank:

It doesn't matter if you work hard and he works little. If your bureaucratic rank is the same, then your salary is the same. It's only in the bonus, when the leaders appraise you, that the difference is made. But they dare not make it too big-they are afraid of creating contradictions among the people, and the people quarreling ( $p a$ qunzhong you maodun, chaojia 怕群众有矛盾、吵架). So the total income difference is still very little [at the same bureaucratic level]. A little difference in bonus is enough to demonstrate the leaders' recognition of one person and warning to another.

Even distribution of bonuses was the norm in SOEs in the early 1980s, and was at that time associated with "worker solidarity". Solidarity was said to depend heavily on workers' close personal ties to other workers and managers. ${ }^{25}$ Such a conclusion may be less appropriate for Tazhi, where distribution practices apparently reflect workers' aversion to criticism by others. Mr Tai, a Workers' Union cadre who describes his own role as "making the workers feel looked after", told me: "Loss is disgrace, but a gain doesn't mean much to an already well-off Tarim employee. If you give them 1000 yuan, they won't say much, but if you take away 100 yuan, they will be up in arms." As with the mooncakes, something expected and then taken away causes an outcry. Expectations are in turn driven by a strong sense of "natural" entitlement that is relative to one's place in the hierarchy. Workers' jealous guarding of such (perceived) entitlements reveals their dependence on the company as their sole source of both income and personal legitimacy.

The productivity bonus is not paid after retirement, but the company runs an in-house retirement benefits scheme to supplement the nationwide scheme. Retirement benefits are just one of many examples in which the Tarim Oilfield Company circumvents national or PetroChina-level regulations to provide extra benefits to its permanent employees. Mr Tai explained that Tazhi set up an "enterprise annuity" scheme because the amount paid to any retiree by a national

\footnotetext{
24. See "Shengchan huinuan wujia shuiping wen zhong you jiang" (Indian Summer for Production: Commodity Prices Are Stable and Falling), Ku'erle wanbao (Korla Evening News) (18 June 2009), p. 1. This figure is disregarded by most people, as misleading at best, if not a complete fabrication. The figure is supposedly based on the average salary of permanent full-time government employees, including teachers and other people in state-funded service units (shiye danwei), and therefore accounts only for people with employment relations with the state (on average, a much better-off population).

25. Wenfang Tang and William L. Parish, Chinese Urban Life Under Reform, pp. 128-32.
} 
retirement fund cannot by law be more than 50 per cent higher than the average retirement pension in the locality that they live-in this case, Korla. Because of their higher salaries, Tarim Oilfield Company employees would have had to pay more into the national retirement fund than do Korla townsfolk. "At the end, if the local average was, say, 1500 yuan/month, we could only get 2250 yuan/ month"-which would be inconsistent with the far larger wage differential. To solve this problem, the oil company set up their own in-house retirement plan, concurrently reducing the official salary (gongzi 工资) component and increasing the bonus as described above. The way that the retirement benefits scheme is set up also helps to explain the fairly even bonus amounts: a large proportion of the bonus is seen by company leaders and employees alike as a part of the entitlement due to a particular bureaucratic rank, regardless of performance-in effect, the basic salary.

\section{Company schools}

Education is significant because of the particularly high value which Chinese parents place on their child's education and its strong correlation with status attainment in reform-era China. ${ }^{26}$ Inside the Tarim compound is the relatively small, but extremely well-resourced, Bazhou Petroleum Number One Middle School. Very few SOEs in China today play such a direct role in the education of their employees' children. The school was eventually transferred from oil company to local government operation in 2010-almost a decade after the original ruling that prohibited SOEs from running their own schools, hospitals and other social services. The delay can primarily be attributed to parents' (oil company employees') extreme reluctance to cede the indirect control that they enjoyed (via the oil company) over the school: school leaders complained to me that, before 2010, they "could not do anything that the parents did not agree with", so the transfer was "not all bad". ${ }^{27}$ Despite the loss of complete ownership, the company still heavily subsidizes education for children of oil company employees. In 2010, construction finished on a completely new high school in Korla's "New City District", which the company then promptly handed over to the prefectural education bureau. Director Xie explained that education remains "a large portion" of the non-cash benefits that the company provides to its employees.

26. Yangiie Bian, "Chinese Social Stratification and Social Mobility”, pp. 99-105.

27. Most of those who thought that the transfer was "not all bad" were the decision-makers and teachers who had no employment relationship with the oil company itself. Both leaders and ordinary teachers who were employed at the Tarim school before 2002 were, or were made, permanent oil company employees at the time of employment (many of them had been transferred from other positions within the oil company). All of the latter to whom I spoke or whose opinions I heard of strongly opposed trading their comfortable positions in the oil company for the status of an ordinary teacher in the prefectural system. 


\section{Gendered career paths}

Perhaps one of the most important, revelatory and socially complex benefits that the company provides to its permanent employees is guaranteed employment for their spouses. The latter are usually women who marry a Tarim employee. ${ }^{28}$ Sometimes these are local Korla girls; sometimes the young man finds a partner in his place of origin; and sometimes these girls are service personnel at the hotels and restaurants out in the desert where the newly arrived graduates spend most of their time. The latter category makes up such a significant proportion of the women who marry into the Tarim compound that there is now a minor industry in positioning young women of marriageable age in service jobs out in the desert. This practice of guaranteeing spouse employment can be seen as the ge-

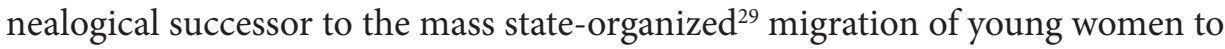
the borderlands of Xinjiang, Heilongjiang and Inner Mongolia in the 1950s and '60s, in order to provide wives to the pioneers of the Production and Construction Corps (bingtuan 兵团), the Forestry Bureau and other state work unit systems. ${ }^{30}$ The goal-providing wives for state workers involved in nation-building on the frontier-is the same. Only the tools have changed, from purely state coercion to a form of market coercion augmented by the oil company's state-granted monopoly position. The Party Secretary of one of two sub-companies which employs these women (post-marriage) explained:

Our work unit's main responsibility is not to seek profits. The main goal is to arrange [work] for oil workers' wives. This is the form of our work unit ... Every year they give us some tens of people to find work for. We just have to arrange work for them in our company, and as long as our company doesn't go bust, we are doing

28. It is apparently rare for the company to take on a new permanent employee who is already married. There may be no single overriding reason for this, but one factor is that the company employs primarily young male recent graduates. This demographic would naturally be predominantly unmarried. These graduates undertake one year of workplace training on probation, and are housed in dormitory-style accommodation. If they were married, the company would be obliged to provide an apartment for them to purchase and also to provide employment for their spouse. For young people looking for employment with the Tarim Oilfield Company (and perhaps many other SOEs in China), it is strategically astute to remain unmarried. In addition, a young man usually needs to establish himself financially and with regard to employment before a prospective wife and her family will consider marriage.

29. My interviews in Xinjiang and Heilongjiang show that "spontaneous" (non-state-organized) marriage migration by women from the inner lands of China was also a common phenomenon during and after the famine of 1958-61. Whether spontaneous or state-organized, a large proportion of these women became workers in collective enterprises that were attached to the large work unit systems, but were not eligible for the full range of benefits (such as pensions and health care) that their husbands enjoyed. Thus, the positions of state worker and collective worker during the Mao era parallel the positions of permanent employee and temporary employee in the present day.

30. I use the phrase "work unit systems" to describe state bureaucratic systems comprised of a large number of separate and all-encompassing work units under the administrative supervision of a single, higher-level entity—usually a Ministry-level Bureau such as coal, oil, forestry, agriculture and so on. 
our job ... As long as this oilfield continues to operate normally, this practice will remain.

The Party Secretary insisted that other regional oil companies in China do not, and do not need to, take care of this aspect of workers' lives as well as Tazhi does. It is necessary in a small place like Korla, he said, because there are few opportunities for "appropriate" and well-paid work. Conversely, he argued, if male workers at oil companies in large cities "can't find an appropriate wife" with a decent job, then that is their own problem: "Nothing to do with the oil company". The wives' jobs are guaranteed as a social service provided by the oil company to the permanent employee husband. Conditions are quite good, ${ }^{31}$ although the women usually remain temporary employees.

The distinction between a male permanent employee and his temporary employee wife reinforces the latter's dependency. I suggest that the initial decision (related by Mary at the beginning of this article) not to provide mooncakes to the temporary employees was not simply because it is an extra cost to the company. Rather, it was also driven by the perceived need to maintain distinctions between temporary and permanent employees. Permanent employees' sense of higher status and their negotiating leverage in the domestic situation is reinforced by such policies. ${ }^{32}$ Furthermore, the exclusion of temporary employees from any entitlement to mooncakes may even be a validation of some permanent employees' own feelings on who should be entitled to what and when-namely, the everyday politics of distribution. The same pattern is then easily followed when it comes to managing and distributing other, perhaps more significant, entitlements and opportunities. More broadly, and undergirding everything mentioned above, such distributions are a restatement of what everybody already knowsthat is, who is of the danwei family and who is not. Conversely, the mooncakes' real value to the temporary employee recipient is in their symbolic inclusion of the recipient in the "family" of the work unit, and in the entitlements' implied statement that the worth of the temporary employee is equal to that of the permanent employee whom they work beside-or are married to.

Oil company promotion practices also affect the career mobility, status and domestic bargaining position of women who are permanent employees. Daisy, a permanent employee teacher whose husband is a rising oil company technician, explained that women are rarely promoted to positions of leadership and

31. The wives are paid about 1500 yuan per month, and at the end of the year they get between 15,000 and 20,000 yuan as a bonus. This is still $25-30$ per cent higher than the average fully employed person in Korla City, particularly as most of these women do not have any skills and only the most basic education. Those who do have skills and education are fostered by the company and put into positions of more importance and responsibility. In this way, they may become permanent employees. The unskilled ones do light gardening work around the compound, teach kindergarten or do manual labor in an oil company factory.

32. Wenfang Tang and William L. Parish, Chinese Urban Life Under Reform, pp. 315-16. 
responsibility, "because their first responsibility is to their family". The expectation that women will perform certain domestic duties on behalf of their husband and child means that "oil company leaders ... cannot make women work as hard as men. If a woman is regularly home late, it will be bad for the harmony of the family." Managers appear to have succeeded in making this gendered inequality into something that is normal and acceptable, at least to the extent that it is not directly challenged:

I think this is bad, but it is right ... I accept my responsibility as a woman ... When I was young, my dream and my goal was to work in a university . . . but now my goal has changed. Now my goal takes into account the reality of where I live and work ... I used to think that my career was important, but now I've given that up and I live for [my husband's] success and for my son; his success is my success.

Daisy's sentiment was echoed by a number of other women in both permanent and temporary positions. Since they have no other option that they are willing to take, these women retreat into pragmatism. The notion that this patriarchal hierarchy is a way of maintaining domestic harmony in the work unit compound also shows that the (almost exclusively male) leaders and male permanent employees perceive it as "the correct order of things", and a sort of "benefit" ( fuli 福利) that they provide to themselves.

\section{Succession}

Educational level is a key variable for inter-generational social mobility in the oil company, and affects different micro-cohorts of permanent employees in very different ways. In mid-2007, the company revoked its policy excluding Tazhi children from employment with Tazhi and, in early 2008, held the first "internal entrance examination". The company had been under pressure for many years from parents concerned for their children's employment prospects, and aware that other CNPC oilfields have always had a system of internal recruitment. To be eligible for the examination, a candidate must be the first child of a permanent employee of the oil company; they must not have accepted a reserved oil company position at university; they must be a recent graduate; and they must have done a four-year degree which is not completely irrelevant to the oil industry. ${ }^{33}$ The first internal entrance examination attracted 23 candidates, of whom 19 gained permanent employment with the oil company. This satisfied most par-

33. Fashion design is the standard negative example here. Tazhi children with qualifications of core relevance to the oil industry—for example, petroleum engineering, geophysical prospecting and so on-are accepted straight into the company. 
ents and is generally seen to be fair and reasonable. ${ }^{34}$ Quite a number of oil company workers noted that the policy "happened to change just as the leaders' children were about to enter the employment market". Some older employees, whose children had already been passed over, were exceedingly angry about it. The timing of this decision was not a coincidence, but it is not only about nepotism: the oil company leaders were among the first university-educated cohort to join the oil company in the early 1990s; and their children graduated from university around 2008. The abolition of the exclusion policy is thus closely linked to social and institutional assessments of the quality of education received by the children born to the earliest cohort of Tarim Oilfield Company pioneers. Most of these pioneers were born in the mid-to-late 1950s, began work at an older regional oil company (like Karamay or Daqing) in the early 1970s, and came to Tazhi in 1986-87. Very few completed high school. This low educational level, combined with the rudimentary conditions of the oil exploration campaign in the late 1980s, means that their children also have a lower educational level than the oil company children who were born and graduated only five years after them.

The exclusion policy reflected the reformist ideals that Tazhi was set up with, while its abolition seems to demonstrate an ongoing and inter-generational nostalgia for the cloistered security and surety of the pre-reform danwei. Compare this situation with that of CNPC's Daqing oilfield, which inaugurated a very similar policy in April 2014, after over a year of decreasing production and profits. The crucial difference was the policy context: previously, Daqing had accepted any oil workers' child holding a higher degree. Thus, while Tazhi’s implementation of an "internal entrance examination" was a concession to the permanent employees, Daqing's implementation of the examination was a limitation. In response, around 2000 Daqing employees and some of their children protested outside the company headquarters, accusing the leadership of corruption and mismanagement, and demanding that the examination requirement be dropped. The protesters expressed a strong sense of entitlement: "We are the children of the oil company; going to work in the oil company is as natural as returning home". ${ }^{35}$ On the second day, hundreds of police were brought in from Daqing City, and the protest met with a forceful crackdown. Emotions were running high: one side saw the reproduction of the family at stake, while the other saw the survival of the corporation at stake. This was a collision between paternalistic

\footnotetext{
34. In addition, Tazhi children who attain Master's degrees in other countries are also automatically employed by the oil company on their return. This is a reflection of both the desire to internationalize the company and the perceived need to provide a way for permanent oil company employees to purchase a secure future for their offspring.

35. "Daqing youtian: shu qian zhigong kangyi gaige zinü bao fenpei zhidu" (Daqing Oilfield: $1000 \mathrm{Em}$ ployees Oppose the Reform of Guaranteed Job Assignments For Their Children), Xin jing bao (Beijing News) (20 May 2014), available at http://www.baike.com/wiki/大庆油田, accessed 4 June 2014; Tian Chen, "Industrial Worry" (19 May 2014), available at http://www.globaltimes.cn/content/861137.shtml, accessed 4 June 2014.
} 
and merit-based ideologies of redistribution. The official line was published in the People's Daily more than three weeks later: "guaranteed job assignments for children of oil workers have not existed for a long time". However, the persistence of what the same author pejoratively termed a "strong oilfield complex"-a sense of entitlement that combines the danwei paternalism of the Mao era with the high salaries and extra benefits of the reform era-was a result of Daqing's hiring practices, which amounted to guaranteed job assignments, irrespective of what the official line was or is ${ }^{36}$ It is ironic that, with regard to inter-generational succession, Daqing is now trying to "learn from" Tazhi. ${ }^{37}$

The example of the internal entrance examination supports Deborah Davis' findings that shifting state policies strongly influence inter-generational mobility, as well as career mobility, within the danwei. ${ }^{38}$ Micro-cohorts still matter in contemporary China, and the effects of privilege or exclusion can reverberate for generations. As the well-known frontier saying goes, "If you give your youth, you give your whole life; if you give your whole life, you give your sons and grandsons".

\section{Formalizing distinctions}

The complex social, economic and spatial distinctions that separate the oil company workforce from its social surrounds and make distinctions within that workforce were emphasized and formalized in early 2009, with the issuing of "smart" identity cards to everyone who lived or worked in the Tarim compound. The card system is an accurate reflection of how the company sees its relationship with, and obligations to, the various sectors of its workforce. Socioeconomic and spatial boundaries had always existed, but prior to the card issue the social boundaries could occasionally be ignored, and the spatial boundaries had been porous.

The "Universal-Use Card" ( yi ka tong 一卡通) is a technology that not only helps to monitor, control and differentiate the population, but also helps to create a desire in them to be classified as internal to the system-and thus to be

36. "Daqing youtian: shu qian zhigong kangyi gaige zinü bao fenpei zhidu”; Xin Lin, trans. Luisetta Mudie, "Police Crack Down on Thousands at Daqing Oilfield Jobs Protest”, Radio Free Asia (9 April 2014), available at http://www.rfa.org/english/news/china/protest-04092014114529.html, accessed 4 June 2014; $R M R B$, “Daqing youtian jinnian yi qianyue 1075 ming biyesheng fei youtian zinü jin jiu cheng" (Daqing Oilfield Has Employed 1075 Graduates This Year; Nearly 90 Per Cent Not Oil Workers' Children) (1 May 2014), RMRB Heilongjiang, available at http://hlj.people.com.cn/n/2014/0501/c220024-21116664.html, accessed 4 June 2014.

37. Tazhi's response to Daqing's small hiring practices reform is yet to be seen fully, but it has already been signaled. A well-connected oil company manager told me in June 2014 that Tazhi's internal entrance examination is likely to become more strict in 2015, suggesting that either Tazhi wants to stay one step ahead in the reform race or that the orders to reform hiring practices come from higher up (CNPC head office or SASAC), or both.

38. Deborah Davis, "Job Mobility in Post-Mao Cities: Increases on the Margins”, The China Quarterly, No. 132 (December 1992), pp. 1062-85; Deborah Davis, “'Skidding’: Downward Mobility among Children of the Maoist Middle Class”, Modern China, Vol. 18, No. 4 (1992), pp. 410-37. 
controlled themselves. Universal-Use Cards allow the user to enter the compound through the security gates that lead to the public area of the riverbank, and permit access to that user's stairwell and use of sporting and recreational facilities, as well as acting as a debit card to pay residential management and utilities fees, to purchase goods from the company supermarkets and to pay for meals at the subsidized company canteens. Each use of the card-when, where and for what purpose-is recorded and compiled in a central database. Should the oil company leaders desire it, they could order the production of a constantly updated cadastral map of certain types of actions by the Tazhi population. "Legibility is a condition of manipulation", asserts James Scott, ${ }^{39}$ and the information provided by these smart cards clearly has profound implications for the maintenance of social order.

Equally significant is the card's explicit role in maintaining a particular social order by classifying and identifying their holders as either A-, B- or C-grade citizens. "A" is the highest rank, issued only to permanent employees of the Tarim Oilfield Company; "A" card holders are able to use the full range of company facilities. "B" cards are subsidiary to an "A" card-they are for children and spouses of "A" card holders and provide the same rights as the "A" card, except that debits for certain services like the exclusive swimming pool must be credited through an " $\mathrm{A}$ " card. "C" cards are issued to contractors and others who need access to the Tarim compound for work, including the Jianghan teachers and the foreign English teachers. Besides access to the compound, the only distinguishing right that " $C$ " card holders are entitled to is use of the company canteen. Bound up as it is with citizenship rights and an implicit hierarchy of worth, the card system immediately became both a status structure and a source of resentment.

The Tarim model, particularly the "new company structure", is the key to enabling Tazhi to perform roles and fulfill responsibilities which appear, on the surface, to be contradictory. Director Xie makes the Tarim Oilfield Company sound very much like a "market-oriented neoliberal" corporation in the US and British mold. ${ }^{40}$ In distinguishing Tazhi from the typical picture of a Chinese SOE with a massive number of employees and burdensome social responsibilities, he rearticulates company discourse. However, the social and economic value of the non-cash benefits due to permanent employees of the Tarim Oilfield Company would appear to undermine Tazhi's apparently genuine attempts to shed social responsibility and employee numbers. These two apparently adverse characterizations can be reconciled thus: rather than the many types of benefits undermining the streamlining effort, the streamlining effort enables the benefits to

39. James C. Scott, Seeing Like a State: How Certain Schemes to Improve the Human Condition Have Failed (New Haven: Yale University Press, 1998), p. 183

40. Anita Chan and Jonathan Unger, "A Chinese State Enterprise Under the Reforms", p. 3. 
be provided. At the core of the streamlining effort is the "three modes of employment" system of classification. There are only a relatively small number of people, either working or retired, who count as full citizens of the Tarim Oilfield Company. The streamlining is not a means to a single end, that is, greater profits, but a means to dual ends which are both important, namely (1) profits and (2) the provision of benefits to the permanent employees.

The structure of the Tarim Oilfield Company both distinguishes it from the socialist-era danwei and shows its origins in the mode of governance that the danwei exemplified. Tazhi is paternalism wrapped in a profit imperative. However, while some of the paternalistic characteristics of the Tarim company are surprisingly persistent, others echo danwei tradition in their purpose but date from the reform era. These latter, including the internal entrance examination and the in-house retirement benefits scheme, can be thought of as reconstituted or, in Harald Bøckman's phrase, "the transformation of tradition".11 Reconstituted benefits take a new form that connects the world inside with the world outside, and exist alongside change and continuity. This dynamic combination contributes to making Tazhi a unique institution, a neo-danwei.

What might be called the outer and inner discourses of the Tarim Oilfield Company-respectively, corporate profit and corporate paternalism-converge in oil company cadres' explanations of this system of distinctions and related benefits. Mr Tai argued that, in order to "attract and keep skilled employees, we need to offer these extra salary benefits, because Xinjiang is not attractive for people to come and live". ${ }^{2}$ "We are profitable, so we are justified in passing on this affluence to our employees", explained Director Xie, without being prompted. His argument unites the shareholder logic of the market with the "one big family" logic of the socialist-era danwei, but it should also be clear by now that the operationalization of this selective paternalism is closely linked to certain intimate distinctions, within the immediate family as well as between co-workers. These distinctions shape the sort of social mobility that is available to different categories of people associated with the oil company.

\footnotetext{
41. Bøckman sets this against "the 'transformation and tradition' scheme". Harald Bøckman, "China Deconstructs? The Future of the Chinese Empire-State in a Historical Perspective", in Kjeld Erik Brødsgaard and David Strand (eds), Reconstructing Twentieth-Century China: State Control, Civil Society, and National Identity (Oxford: Clarendon Press, 1998), p. 311.

42. Since job mobility in SOEs is perceived to be low, and Xinjiang is still seen as the backwoods, moving from eastern China to an SOE in Xinjiang to settle and work is usually regarded as a lifelong commitment. There is an inbuilt assumption here that there is not enough skilled labor available in Xinjiang, and that the "quality" of people from Xinjiang is inherently low. Therefore, the salaries and benefits must be particularly high - as one informant put it, the material conditions in Tazhi "are certainly a match for most places in eastern China". Director Xie asserted: "You have this overseas as well-all big companies do this. It is a method, a system that attracts skilled people. It says 'this enterprise is good', because only good enterprises can afford to do this. Another thing is that skilled people will stay on with the enterprise, not betray it. This is a usual practice of SOEs."
} 


\section{THE CONSTRAINTS OF PRIVILEGE IN AN SOE}

Expectations of social mobility among Tarim Oilfield Company employees are status-specific and vary greatly but, at some point, most people find their ambitions constrained-if not by their own aversion to risk, then by that of the company itself. The rhetorical question asked of Mary when she first arrived in Tazhi- "Why do you study? Your salary is not related to your labor" - highlights how little has changed from the ideal-typical danwei of the socialist era. To the lower-level temporary and permanent workers, "lifetime employment" means doing the same job for life. The question was, of course, also a warning to her: "do not get out of line; do not rise above us". Her co-workers were desperate to make her like themselves, as comfortably immobile as they themselves felt. The perception that almost insurmountable constraints affect their own social mobility, moreover, is not limited to lower-level employees.

Ren and Jing, a couple of middle-ranking cadres who have been with the company since they started their careers in the early 1990s, explained that they, too, are constrained by comfort, as well as age and educational level: "We work for a state-owned enterprise-it is extremely difficult to change locations". They assured me that they have little alternative but to stay with the company until they retire: "We would be hard-pressed to find any workplace that offered us conditions as good as here-wouldn't such a good workplace only accept younger people, or people with MAs and PhDs? This is about knowing yourself . . you can't just run wildly all over the place." The examples given so far in this article concur with a large amount of empirical research that educational level is a key influence on opportunities for social mobility in post-reform China, ${ }^{43}$ but Mary's view (outlined below) demonstrates that education alone is insufficient.

The dynamic tension between social mobility and job certainty is evident in the way that Mary views the career pathways open to her. Although she has a Master's degree, she would need to become a permanent employee before she could be promoted. She complained that temporary employees get given all the bad jobs, no matter how well they perform or how hard they work. At the same time, as the wife of a permanent employee, she can never be fired. She occupies a position within the élite, but outside the core. She told me that, upon her return to Beijing, she hoped to get a permanent job with the oil company, but even this ambitious and well-educated young woman did not rule out staying on as a temporary employee. An undemanding, dead-end job is abhorrent to her, but

43. See, for example, Andrew G. Walder, "Career Mobility and the Communist Political Order", American Sociological Review, Vol. 60, No. 3 (1995), pp. 309-28; James Raymo and Yu Xie, "Income of the Urban Elderly in Postreform China: Political Capital, Human Capital, and the State", PSC Research Report, Vol. 97, No. 404 (September 1997); Martin King Whyte and William L. Parish, Urban Life in Contemporary China (Chicago: University of Chicago Press, 1984). 
the security and relative prosperity remain attractive. Such an attitude is far from unique to China, of course, but the competitive nature of the employment market and an inadequate social security system constitute particularly strong incentives to seek personal material stability in the public sector.

Social mobility beyond the oil company is available only to the most outstanding (and courageous) candidates. A couple of examples illustrate this point. In more than two years living in the company compound, and with increasing numbers of employees wishing to get out of Xinjiang because of the rising inter-ethnic tension, I nevertheless heard of only one non-managerial employee who left his permanent position to take up a job elsewhere. Two different people mentioned his story to me, without prompting and with palpable respect in their voice, suggesting that such action was something of a local legend, not a common occurrence. The "escapee" was a highly skilled technician who emigrated to North America. Only after arrival did he secure a job with a large Canadian oil firm, and is now apparently very well paid with "a large freestanding house" and "a number of children" (such are the symbols of masculine success). A second instance was Director Xie. A few years after I first interviewed him, Director Xie secretly quit his job to "go it alone" (ziji gan 自己干) in east China. "Going it alone", in this case, meant moving into an executive position with a private oil-industry-related company. There was not much "upside" left for him in Tazhi-he had been there for 20 years, and had gained rapid promotion before being sent to get an MBA in the US at company expense, then further promoted soon after return. At that level of the Tarim Oilfield Company, however, his skills were under-utilized; higher positions in the administration were increasingly political in nature. Xie lay low and stayed incommunicado for six months following his rapid (but obviously planned) resignation, suggesting that leaving the oil company is no simple matter for that small proportion of employees who are in demand elsewhere.

\section{The "Hard Target" of Stability}

Bureaucratic incentives to maintain stability also exert a strong influence on activity, achievement and aspiration in the oil company. Tazhi is known to be the most strictly governed work unit and residential compound in Korla, and its governing practices blur the boundaries between the work and living environments. For example, renting out an apartment in the Tarim compound is a riskier proposition than in Korla City, because the owner of the apartment takes responsibility for the behavior of the tenants. If the tenants breach a safety regulation, or an accident such as a kitchen fire occurs in the rented apartment, the apartment owners and all the people in their work units, as well as the tenants themselves, will be penalized. They may, for example, lose one month or even an entire year of salary bonuses, depending upon the severity of the breach. This system is officially known as “joint responsibility” (liandai zeren 连带责任) and more colloquially 
"guilt by association" (lianzuozhi 连坐制). The system of “joint responsibility" is an integral part of the social control mechanism within the Tarim compound and the oil company's work units. A number of oil company employees independently asserted that the leaders "put joint responsibility into practice whenever and wherever they can". Although many of these employees seemed to resent the practice in some respects, most also reflected that the system of joint responsibility did serve a useful control function.

Along with safety and security, breaches of the family planning regulations are most heavily penalized. The careers of local police officers and work unit leaders can be severely compromised if just one of the people that they are supposed to be keeping an eye on exceeds the birth-control quota or causes a major accident. These two hyper-sensitive areas are said to attract a "one vote veto" ( yipiao foujue 一票否决) 一 that is, one mistake in either of these areas is enough to stop a career in its tracks. Hence, these areas are very tightly controlled, and all sorts of coercive measures (mostly, but not exclusively, focusing on penalties rather than rewards) are deployed.

Tazhi's own imperatives of social and economic stability temper the ambitions of its employees, as demonstrated by Party Secretary Zhang's story. Zhang's first major assignment after starting work in 1992 was a poisoned chalice: he was sent to manage a failing chemical factory that was producing an environmentally harmful product that nobody wanted. Zhang had no capital and only antiquated existing equipment, but by slightly changing the product that the factory was making, he increased sales tenfold in the first year. By the time he left seven years later, he claims that the factory's economic output had grown 52 times.

Zhang related with some disappointment how cadres' promotion in the oil company depends less on making outstanding achievements than on avoiding outstanding mistakes. He explained that his leaders did not want him to grow the chemical factory further because "[they] seek only stability. There is no benefit to them of making [the factory even more profitable], and there is much to be lost in making it worse." Zhang reflected on this situation, commenting that, although the speed of development is slower under this system, it does have the advantage of minimizing the risk of spectacular failures. Out at the factory that he currently manages, the conditions are good and the work is not hard, but he lamented the bureaucratism: "Anything that you want to do, you have to get approval from higher levels ... You can't just operate the factory as you see fit - that's not okay ... My feeling of success is not as good as at the old factory."

In spite of some resentment from mid- to lower-level oil company employees towards the strict governance applied to them, controls are seen by this élite group as valuable-worth sacrificing some of your own freedom to secure. Both explicit and implicit discourses assert that only top-down control, strict security measures, hierarchy and rigid rules are sufficient to keep the destabilizing and unpredictable elements of society in check (including those close by and even 
inside one's own work unit). Thus the Tazhi hierarchy and the system of "joint responsibility" are accepted.

The people who live in the Tarim compound are, outwardly, models of a harmonious society. In this sense, they differ from the well-off residents of gated communities in Beijing, which Luigi Tomba described as one of the "most contentious and rebellious social groups in late socialist urban China", ${ }^{44}$ but they are also similar, insofar as the Tarim compound provides a tangible model of socioeconomic aspiration. Although the model can create resentment, its presence at least creates an opportunity for administrative rhetoric to proclaim that material advancement is not only possible but also happening in Xinjiang and, further, that stability and (therefore) material privilege owe their existence to CCP rule and to the attendant political assumptions and behavioral expectations. The message is: if you want to be rich, you have to be obedient, high-quality citizens.

\section{CONCLUSION}

Many of the attributes that we associate with the traditional danwei are present in Tazhi. These include the gated compound, the all-encompassing benefits and services due to the permanent employees, the complex structures of dependence, the difficulty of getting in (and out) as an employee, and the low career mobility within the work unit. The oil company claims to have done away with more of the old danwei characteristics than it actually has. But there is more to Tazhi than being a replica of the socialist-era danwei. Tazhi has also abolished certain traditions, and transformed certain others. Market practices and the reconstitution of danwei-like practices render simplistic characterizations inappropriate. Established in the first decade of the reform era, Tazhi is an artefact of transition.

Expectations are formed within this environment. The formal structures and managerial practices of the Tarim Oilfield Company are more or less accepted by the various classes and ranks of employees, and sometimes they are even internalized. For example, the views of some women who see their place as "primarily in the family" 45 are shaped by the formal and informal structures that make them dependent by restricting, or denying altogether, their career mobility in the workplace. Second, even skilled male technicians and researchers do not expect to rise far in the hierarchy unless they switch to a managerial career; this echoes the old worker-cadre distinction. ${ }^{46}$ Third, Tazhi permanent employees expect that their children will be given preferential entry into the oil company, but their expectations are still lower than those of employees in the more traditionally structured Daqing oilfield company. Fourth and finally, among the permanent employees, bureaucratic rank is widely accepted as a justification of

44. Luigi Tomba, "Making Neighbourhoods", pp. 57-58.

45. Yangjie Bian, "Chinese Social Stratification and Social Mobility", p. 103.

46. Andrew G. Walder, "Career Mobility and the Communist Political Order". 
sometimes quite widely differing material and status entitlements. Maintaining the consistency of entitlements at each level of the hierarchy-rank-based equality-appears to be more important to the employees than addressing the underlying logic of the hierarchy itself. Consistency and predictability are valued. For these employees, being judged "not inferior/behind" by a superior is more important than being judged as "outstanding/advanced". I suggest that this is a direct reaction to the ranking system itself: they need to know exactly how they stand in relation to the people with whom they interact on a daily basis. They need to know what treatment, both material and social, to expect from these people, and how they are expected to treat other people-and even whether they ought to be socializing with them at all. The ranking system provides a clear guide to these social and economic ambiguities. Thus, part of the explanation is structural: rules create expectations.

Similarly, many people choose to follow career and life paths that are constrained but allow them to reach a known and, for them, acceptable status. The path is predictable and safe. Often, they are unable to move very far beyond this acquired status. Psychological and formal dependence on the work unit makes individuals more accepting of the rules that determine social mobility. Dependence makes people compliant, and is accentuated in Tazhi by certain sociospatial factors: there are no employers out on the frontier, except other Central SOEs, that offer benefits that are anything like comparable; and Han people who are in this danwei all realize that they are at the periphery of their own empire-state. With regard to their work unit status and material conditions, they have reached "somewhere", but, culturally and spatially, they are still in "the middle of nowhere".

This is one of the really interesting things about China-that people still really aspire to work in such a danwei, rather than in an environment where there is more potential for mobility and more capacity to shape one's own career and identity. I favor the simplest explanation: people who come into the oil company (and other work units with similar attributes) accept the structures of dependence and the constraints on their own future mobility as the price of privilege. Dependence allows the temporal stability needed for social reproduction; socioeconomic stability seems to be the most sought-after privilege. Such certainty allows planning and social reproduction in a broader environment (contemporary China) that has a history of, and is still seen as liable to, rapid change. Privilege, here, equates to certainty.

Individual, institutional and statist desires for stability converge in Tazhi. People seek certainty in an uncertain world, and many are willing to trade off against possibly greater potential: "a bird in the hand ...". In this way, material stability itself becomes an element of status, something to be envied. The state and the institutions of the state seek social and economic stability to perpetuate their rule or their paramount position. Social and institutional reproduction, respectively, are the nostalgic aspirations of post-socialism. 